\title{
ACTION LEARNING IN INTERNATIONAL SETTINGS: POSSIBILITES FOR DEVELOPING ORGANISING INSIGHT
}

\author{
Dr Amanda Hay \\ Nottingham Business School \\ Nottingham Trent University \\ Burton Street \\ Nottingham \\ NG1 4BU
}

Tel no: 01158486118

Email: amanda.hay@ntu.ac.uk

Dr Amanda Hay is Senior Lecturer in Human Resource Management and Organisational Behaviour at Nottingham Business School. Her research interests primarily lie in the area of management learning. Her recent work explores the ways in which management education is seen to contribute to management practice and managerial careers. In addition, she has an interest in understanding emotion in management learning.

Submission category: Academic Paper 


\section{ABSTRACT}

Action learning approaches are seen to offer promise to troubled MBA programmes in providing increased attention to practice. However, whilst there is broad support for the use of action learning in management education, in practice its use is limited and issues remain in respect of the form it takes. Calls have therefore been made for research into the use of action learning as used in management education contexts to facilitate its diffusion and adoption. This paper provides an empirical consideration of a particular form of action learning: an MBA international consultancy project. Drawing upon student interviews the paper suggests that the form of action learning used here was imbued with opportunities to develop 'organising insight' (Vince, 2004). Furthermore, the paper highlights that the unfamiliar international location was especially significant in developing such insight. The paper suggests that forms of action learning which accentuate the unfamiliar can be of significant benefit in helping managers to understand taken for granted aspects of practice and thus provide particular promise for progressing critical management perspectives. In getting closer to practice, there is value in the use of teaching approaches which on face value might be seen to take managers further away from everyday practice.

Key words: action learning; international; organising insight, emotions, politics, MBA 


\section{INTRODUCTION}

Over recent years, criticisms of management education generally, and MBA programmes specifically, have intensified with many questioning the relevance and effectiveness of business school offerings (Pfeffer \& Fong, 2002; Mintzberg, 2004; Starkey et al., 2004; Bennis \& O'Toole, 2005,). In respect of MBA programmes, it is contended that both the content and teaching methods employed significantly contribute to such failings (Mintzberg, 2004). Accordingly, there have been growing calls for revised content and alternative teaching methods.

In respect of teaching methods, MBA programmes stand accused of a reliance on traditional classroom methods such as the case study which privilege artificial problem solving and although provide some help in the study of management are said to be unhelpful in teaching management. Bailey and Ford (1996: 9) contend that "the practice of management is best taught as a craft, rich in lessons derived from experience and oriented toward taking and responding to action". Accordingly, critics suggest that MBA programmes should place greater emphasis upon experiential learning methods which promise increased attention to 'real world' problem solving and hence practice (Grey, 2004; Mintzberg, 2004; Navarro, 2008).

Action learning represents one of the most commonly used forms of experiential learning, emphasising learning by doing and since its promotion by Revans in the 1980s, has periodically offered solution to some of the 
problems of traditional management education (McLaughlin \& Thorpe, 1993, Rigg \& Trehan, 2004). Moreover, recent developments suggest that not only does action learning provide opportunity to work on 'real world' problems but also is a potential vehicle for introducing critical management perspectives. Broadly, such perspectives offer a challenging view of management as a social, political and economic practice (Grey et al., 1996; Reynolds \& Vince, 2004), and as such are argued to more closely resemble the complexities of practice (Grey, 2004). Action learning thus offers much promise for the troubled MBA programme.

However, whilst there is broad support for the use of action learning in MBA programmes issues remain. One important issue is the specific form action learning takes. Gosling and Mintzberg (2006:426) for example, have queried the extent to which managers need more action, suggesting that action learning might be "a fine idea, so long as the action is real, not added in some artificial way". They argue that projects ought to be based on what managers are already doing in the workplace, in their words, "to use work, not make work" (p.420) which challenges forms of action learning involving external projects. Questions of form aside, survey research by Pedler et al. (2005) suggests that in practice business schools make only very modest use of any action learning and that management educators are generally unskilled in its use. They make calls for "publicising and disseminating what is already known as well as what may be new" (p53) to facilitate the contribution of action learning to management education. This is echoed by Johnson and Spicer (2006) who suggest that there is a lack of understanding of action learning as 
used within management education contexts and call for more research into the process and effectiveness of action learning to aid its diffusion and adoption.

This paper responds to calls for more research which explores the use of action learning within management education contexts, and seeks to add to scholarship on action learning as a pedagogy which Dehler (2006) contends is underdeveloped. Specifically, the paper presents an empirical consideration of a particular form of action learning which has not been previously documented: an international consultancy project which constitutes a module on a part-time UK MBA programme and involves a week spent overseas tackling real organisational problems for external organisations. Given that the projects described here involve working on problems for external organisations, it should be noted that the projects for some might not represent examples of 'pure' action learning but nevertheless are consistent with its key principles (Pedler, 1997). Indeed, Pedler et al. (2005) note the wide variations of action learning in practice and draw particular attention to adaptations apparent in Higher Education. It is thus suggested that the particular adaptation of action learning here in being removed from the manager's everyday practice which to use Gosling and Mintzberg's (2006) terms, 'makes rather than uses work', provided special learning opportunities.

Drawing upon students' project accounts, the paper suggests that the action learning in international settings described here presented an unusual degree of space for taken for granted aspects of practice to reveal themselves. 
Specifically, it is suggested that taking the manager 'out of place' accentuated possibilities for raising awareness of the emotions and politics which surround efforts to organise. The paper empirically demonstrates the position of Vince (2004) which contends that there is much that remains to be said about the ways in which action learning offers opportunities to learn from organising and to develop what he terms 'organising insight'. Moreover, given that the emotional and political are salient features of critical management perspectives, the paper offers rare empirical support for the espoused synergies between action learning and critical management education, and proposes that in particular, the unfamiliar in action learning projects may be especially significant for progressing more critical understandings of practice.

The paper is structured as follows. The paper begins by considering the action learning literature highlighting how recent work has built upon the pioneering work of Revans (1980) to privilege emotional and political aspects of learning, and as such offers promise for leveraging critical management ideas. A description of the research methods and details of the action learning project are then provided. Students' accounts of their projects are then presented which evidence possibilities for developing 'organising insight' and suggest the benefits of viewing action learning as a process of organising (as well as a process of learning) (Vince, 2004). In developing organising insight, particular attention is drawn to the manager being out of place. The discussion and conclusion subsequently suggest the value of action learning projects which heighten the unfamiliar, and in so doing illuminate taken for granted aspects of management practice. This can promote critical 
understandings of management practice and ultimately more reflexive practice.

\section{ACTION LEARNING}

Action learning is traditionally associated with the work of Revans (1980, 1982) and offers an alternative to conventional forms of management education and development, with their focus on programmed knowledge (Mc Laughlin \& Thorpe, 1993; Raelin, 1994). Indeed, recurrent problems facing MBA programmes are in part seen to be linked to an overemphasis upon such knowledge (Leavitt, 1989; Mintzberg, 2004). Whilst not dismissive of programmed knowledge, Revans's approach fundamentally emphasises learning by doing, offering a way of developing managers, by bringing together groups of managers to work in teams on real work-based problems (Pedler, 1991; Marquardt, 1999). Revans (1982: 626-7) defines action learning as

'a means of development, emotional or physical that requires its subjects, through responsible involvement in some real, complex and stressful problem, to achieve intended change to improve their observable behaviour henceforth in the problem field'.

It is suggested that action learning provides for both positive organisational impact and individual development.

Revans's approach suggests that individual development is facilitated through reflection upon and questioning of attitudes and actions when solving real 
organisational problems (McGill \& Beaty, 1995; Marquardt \& Wadill, 2004; Raelin 2006, Harris, 2006). Indeed, Revans (1982) proposes that Learning $=$ programmed knowledge + questioning insight. For Revans, finding the right question to ask is of crucial importance to the success of action learning. The site for such questioning is the action learning set or group. This small group meets on equal terms to report to one another and discuss their problem and progress (Revans, 1984; Smith \& O' Neil 2003) and reflects a belief in the value of managers learning from and with each other. Revans (1982) suggests managers can be seen as 'comrades in adversity' working together to overcome obstacles to problem resolution.

Action learning is therefore seen to comprise three major elements:

1. people, who take responsibility for taking action on a particular issue;

2. problems, or the tasks that people set themselves; and

3. a set of six or so colleagues who support and challenge each other to make progress on problems (Pedler, 1997; Marsick \& O’ Neil, 1999).

Action learning as developed by Revans thus privileges the progression of problem resolution and organisational impact which is seen as crucial to effective learning. Therefore Revans's original ideas hold particular promise for MBA programmes which stand accused of limited application in practice. However, more recent work suggests that action learning holds further possibilities for management education which are downplayed in its original form. 


\section{Action Learning as an Organising Process}

If the full potential of action learning is to be realised in getting closer to the complexities of management practice, it is suggested that in implementing action learning into MBA programmes, educators embrace the broader opportunities that action learning offers. Specifically, it is increasingly recognised that action learning allows much space for the exploration of social and political aspects of practice (Anderson \& Thorpe, 2004; Reynolds \& Vince, 2004; Rigg \& Trehan, 2004, Vince, 2004; 2008).

Although Revans's position acknowledged social and political aspects of action learning, he did not see these as central to learning and his work has been questioned for underestimating their importance and complexity (McLaughlin \& Thorpe, 1993; Pedler, 1997). Similarly, Vince (2004) suggests that a focus on 'comrades in adversity' emphasises all that is positive in togetherness whilst neglecting the inevitable troubles present when individuals work together, equally he suggests action learners can be seen as 'adversaries with commonality'. More recent work therefore returns to the social and political issues involved in action learning and seeks to develop these under acknowledged features (Rigg \& Trehan, 2004; Vince 2004; 2008, Gentle, 2010). Rigg and Trehan (2004: 150) for example propose that the "tensions, contradictions, emotions and power dynamics that inevitably exist both within a group and in individual managers' lives" are a central site for learning in action learning approaches. 
Indeed, Vince (2004) places such dynamics at the centre of action learning in his development of Revans's original theory. He contends that traditionally action learning has been understood in terms of the impact it can have within the organisation through individuals' attempts to solve organisational problems. He asserts that in addition we might also usefully ask: what is the impact of organisation on action learning? This suggests that action learning can also be seen as an organising process (as well as a learning process) and as such is concerned with an 'engagement with existing organisational dynamics and power relations mobilised by attempts at learning and the influence they inevitably have on the outcomes of learning' (Vince, 2004: 63). $\mathrm{He}$ contends that this is precisely because action learning requires involvement in 'real problems' and as such can not be isolated from surrounding organisational dynamics. As Vince asserts our attempts to learn and to organise

'are complicated by political decisions, alliances and strategic choices; by fantasies and interpretations of the behaviour and motives of others; by individuals' desires to control or avoid; by fears and anxieties; and by broader organisational power relations that represent "how we do things here' (p.64).

In particular, Vince's account thus draws attention to emotions and politics which arise from attempts to learn and to organise which tend to be downplayed in traditional understandings of action learning (Vince, 1996; Elliott, 2005). 
This reflects a broader disregard of emotion and politics in organisations more generally which is surprising since organisations are inherently emotional and political places (Fineman, 1996; Vince, 1996; Antonacopoulou \& Gabriel, 2001). Our emotional responses or indeed attempts to avoid negative emotions inevitably inform organising. For example, Vince and Martin (1993) illustrate the ways in which working with anxiety can allow for new organisational insights, and its avoidance in contrast may promote willing ignorance. Furthermore, emotion both informs and is informed by organisational politics. Politics which can be seen to include both internal organisational politics which reflect relationships between individuals and groups, as well as social politics which are located in and reflect broader social contexts, both significantly shape what is possible in organisations (Vince, 2004). Arguably, given the importance but neglect of such organisational dynamics, there is a need to identify ways of raising management students' awareness of such issues to facilitate deeper understandings of practice.

It is suggested that action learning seen as a process of organising, provides one important space in which organisational dynamics can be explored. Vince (2004) thus suggests that in addition to Revans's questioning insight, action learning also offers possibilities for the development of organising insight which is to learn from organising through an examination of politics and emotions integral to organising. The addition of 'organising insight' can be seen as beneficial since it raises awareness of taken for granted aspects of practice which nevertheless have significant influences on what is possible in 
organisations. Attention to organising insight in action learning approaches thus provides special opportunities for management educators seeking to facilitate managers' understandings of practice. Moreover, the addition of organising insight to understandings of action learning has obvious synergies with critical management perspectives since the emotional and political are salient aspects of critical understandings of management practice which emphasise management as a socially organised rather than technical activity (Watson, 2002, Willmott, 1994). Action learning more generally thus offers opportunities for leveraging critical understandings of management practice. Whilst others have of course recognised these opportunities (Wilmott, 1997; Anderson \& Thorpe, 2004; Rigg \& Trehan, 2004), Reynolds and Vince (2004) argue that the synergies between action learning and critical management education have not been sufficiently championed.

Indeed, scholars have noted that whilst re-conceptualisations of action learning approaches suggest much promise for the promotion of more critical understandings of management practice, this promise largely exists at a conceptual level and highlight a lack of supporting empirical evidence (Pedler et al., 2005). The paper therefore seeks to contribute by providing an empirical example of how a particular form of action learning as used on an MBA programme provided unusual opportunities for developing organising insight and more broadly leveraging critical understandings of management practice. 


\section{RESEARCH METHODS}

The work drawn upon here was part of a larger study of MBA alumni which sought to understand the ways in which their MBA experience was seen to contribute to management practice and careers (Hay \& Hodgkinson, 2006; 2008). Since there is a paucity of research which explores MBA programmes from the perspective of those that have actually undertaken them (Mintzberg, 2004), the study adopted an interpretive research approach with an emphasis on 'understanding the complex world of lived experience from the point of view of those who live it' Schwandt (1994: 118). There was thus a concern to privilege students' accounts of their MBA experience.

The field work took place at a single site with students taken from a range of MBA cohorts since the original intention of the project was to understand the benefits of studying on a particular MBA programme as seen by its alumni to inform its future curriculum development. Whilst the limitations of single site research are acknowledged, the sample included a cross section of MBA students and the insights offered are potentially relevant to other institutions. The business school here belongs to one of the leading UK 'new universities', and whilst its MBA programme is not accredited by bodies such as AMBA or EQUIS, the MBA programme had enjoyed a good reputation based upon its vocational leaning. Accordingly, the MBA programme had made use of action learning methods for many years. The sample consisted of a total of 35 alumni from the part time MBA programme, 19 males and 16 females aged 
between 29 and 56 years old, the majority of whom had worked for up to five years post graduation. Those interviewed came from a variety of job backgrounds, spanning private, public and voluntary sectors. All were UK students. As is commonly found in qualitative research studies, purposive sampling was used which enabled the use of judgement to select cases which best helped in answering the research questions (Miles \& Huberman, 1994).

Data were collected through the use of in-depth interviews. Each interview lasted between 1 and 2 hours, and took place at either the manager's workplace, or at the university. The interviews were semi-structured and asked managers to describe their careers to date, the challenges of their current role, their manager learning generally and their MBA learning in particular.

The interviews were recorded and fully transcribed. The study utilised an inductive approach to data analysis following guidelines develop by Strauss and Corbin (1998). Given the underdeveloped understanding of the ways in which MBA programmes are actually experienced by students, an inductive approach was felt to be more sensitive to unanticipated outcomes. Thus my understanding of managers' MBA experiences emerged through an iterative process of research and analysis with the use of Nvivo coding in relation to emergent themes. Initially, an open coding process was employed through reading and re-reading the transcripts, allowing concepts to emerge from the findings. Emerging concepts were given codes and organised into possible categories. A salient category which emerged was the value of the 
international consultancy project to the MBA experience. In turn the analysis then sought to identify specific ways in which the projects were seen to provide valuable learning. Data were thus coded according to the challenges of group working and the international dimension of the project at the various project stages e.g. project introduction and definition, fieldwork experience.

It is important to note that Strauss and Corbin's position accepts the salience of the researcher's accumulated knowledge, recognising how this informs and develops emerging ideas. As the analysis progressed, the significance of emotional and political aspects of the projects emerged and was related to Vince's (2004) perspective on action learning. Thus the approach employed here recognises the influence of the researcher on the analysis process who is seen to make sense of the data retrospectively not prospectively (Wright, 2008). However, as Watson (1994: 79) helpfully elaborates, 'management researchers select, interpret, colour, emphasize, and shape their findings. But they do not invent say, the machines they write about or the experiences of redundancy of the people they review'. Accordingly, the analysis offered here reflects my interpretation of the students' accounts of their action learning projects. Before presenting student accounts of their learning, an overview of the action learning project is first provided. 


\section{AN ACTION LEARNING EXAMPLE: AN INTERNATIONAL CONSULTANCY PROJECT}

\section{Project overview and aims}

The MBA programme here includes an international consultancy project which involves students spending a week overseas working together in groups on a real world problem for a host organisation and is designed according to the underlying ideas of action learning. Indeed, De Fillipi (2001) notes that the use of projects for learning is typically associated with action learning principles. As described by the programme literature

'the key objective of the project is to allow MBA students to undertake a live international consultancy task, preferably with a strategic management dimension, that impacts directly on the present or future performance of an appropriate host organisation'.

In line with Revan's (1982) conception of action learning, the international project emphasises learning by involvement in a real world problem with an intention to impact upon organisational performance.

\section{Project Definition}

In defining the project, groups act autonomously with minimal involvement from faculty, with the terms of reference provided by the university left deliberately wide to promote freedom of choice of the country and industry to be selected, and the nature of the project envisaged. However, the project 
proposal has to be approved by the university. The project requires students to form into self selected groups of four to six which establish the action learning group. In accordance with the principles of action learning (Pedler, 1997; Marsick \& O'Neil, 1999), it is the responsibility of the groups to identify a suitable host organisation and with the host, negotiate the exact focus of the problem to be tackled. It is important to note that the project involves the progression of a real problem not simply one manufactured for the set (McGill and Beaty, 1995). The discussion of the problem is seen to be an important element of the learning process promoting responsible involvement in the problem area (Revans, 1982).

\section{Project preparation}

Following project approval, groups are required to undertake a number of preparations ahead of the overseas visit. At this stage, in step with the key principles of action learning, groups take decisions regarding the allocation of individual responsibilities and research the country, business sector and host organisation. Students are also responsible for organising all aspects of the visit. Further, the groups often comprise individuals from diverse occupational areas which pose additional challenges. As such, students are required to consider how the group will work together and the personal qualities that each member brings. To aid this process, students complete team inventories such as Belbin or Myers Briggs. The process of identifying and preparing for the project takes around six months. 


\section{The Field Experience}

Projects are carried out by groups in the spring term of the second year of the MBA and are varied both in terms of content and location. Projects have focused on for example, strategic reviews, international branding development and teamworking, in a variety of organisations spanning private, public and voluntary organisations. Projects have been carried out in countries worldwide including Belgium, Germany, Malawi, Malaysia, Poland, South Africa, USA and Vietnam. Of interest, the international location of the project provides an unfamiliar setting for the majority of students since their managerial roles rarely include international responsibilities. For many, the content of the project is also unfamiliar as it is removed from their functional expertise. For some writers, unfamiliarity of the task is of importance since it is seen to promote questioning insight (McGill \& Beatty, 1995; Raelin 2006).

\section{Project assessment}

For assessment purposes, groups are required to produce a report of 4-6000 words responding to the outlined terms of reference negotiated with the client. The assessment criteria focus on the extent to which groups are able to identify and develop an appropriate organisational issue which is subsequently usefully researched resulting in recommendations for action for the organisation. Groups however lack authority to implement recommendations, and for some this may be problematic. Inglis (1994) for 
example argues action must be taken not just recommended. However, as will be seen, this does not deny the rich learning possibilities presented.

\section{DEVELOPING ORGANISING INSIGHT}

The analysis of student accounts' suggested that the international project offered a valuable and intense experience which offered learning opportunities which extended beyond instrumental problem solving concerns espoused by the programme literature. The accounts emphasised a description of action learning as an organising process and demonstrated that this form of action learning in practice was imbued with opportunities to develop 'organising insight' (Vince, 2004), that is, to learn from and about the emotions and politics surrounding learning and organising. Of note, the analysis suggested that the unfamiliar international location was especially significant in developing such insight for a number of reasons. Firstly, the international action learning project presented an unfamiliar challenge which required considerable sensemaking (Weick, 1995). This stimulated much emotion which was further complicated by action learning's requirement of group working which heightened political concerns. Secondly, the unfamiliar international location provided an experience of 'otherness' (Chia, 2010) and drew attention to societal differences which were important in elucidating broader social politics. Below, firstly illustrations are offered from the various stages of the project which shed further light on the ways in which organising insight developed in practice and are summarised in table 1. The illustrations serve to draw attention to what might be seen as rather mundane features of 
the projects which nevertheless present important opportunities for educators to facilitate students' understandings of emotional and political aspects of practice. Secondly, the analysis provides examples which demonstrate the ways in which raised awareness of emotions and politics surrounding their action learning projects, informed a more reflexive practice.

\section{Project introduction and definition: Addressing the unfamiliar}

The accounts suggested that the early stages of the project presented opportunities for educators to raise awareness of emotional and political aspects of practice. Fundamentally, the analysis highlighted that the introduction of the international project posed an unfamiliar challenge which served to disrupt individuals' known ways of doing. Consistent with Weick (1995), such disruption could be seen to stimulate much emotion as students made sense of the unfamiliar assignment: 'I must confess that when I first read about the international consultancy, I actually felt daunted by the prospect [Manufacturing Manager]. In accordance with Vince (1996), this apprehension partly related to the unusual responsibility placed upon the student, 'we had little support at the front end and it made me feel very uncomfortable' [Operations Centre Manager]. Of significance, the analysis further revealed that such discomfort was especially associated with the international requirement of the project here. For example, anxiety was expressed in contemplating the projects' location: 'you move beyond your comfort zone: there are obviously language barriers but also you don't know how that country works, where do you go to in another country to get 
information?' [Operations Centre Manager]. The unfamiliar international location thus amplifies anxiety which leverages opportunities to raise students' awareness of emotional aspects of practice.

Moreover, since the project required individuals to work in groups, opportunities to illustrate the interaction of emotion and politics were also evidenced as individuals worked together to define the parameters of their projects. The analysis revealed that varying individual responses to the anxiety of the international location raised some issues. For example, some group members, sought to avoid anxiety by proposing nearby locations 'And other people saying 'Oh God we have got to be away for a week, I want it to be in Europe because it is only a two hour plane flight' [Communications Manager], whilst others embraced anxiety and recommended distant locations:

'I mean apart from a French exchange and a yearly beer trip to Belgium,, that is my globe trotting done, Malaysia is somewhere that I never even contemplated going' [Contracts Manager].

Furthermore, project location choice also surfaced broader learning orientations towards the MBA programme which presented further issues in working together to define the project. For some, the project represented opportunities to do 'something different' and to 'make a difference', whereas for others the project was viewed in much narrower terms being seen as an 
obstacle to be overcome in order to 'pass the course', an opportunity for personal career gain or an excuse to party:

'We were five individuals... we came from totally different backgrounds and we all had our own personal agendas as far as the MBA was concerned....one of the group had chosen to visit the hospital in the Czech Republic because she thought it would further her career whereas the other four of us just wanted to do it because it was something totally different to what we were doing in our everyday work lives' [Business Development Manager]

'I think there was an issue for me. I think partly because the others saw it as a week long piss up and I didn't' [Strategy Manager]

The examples illustrate how learning is both desired and avoided (Vince and Martin, 1993), and indeed, how competing individual responses inevitably shaped the groups' possibilities drawing attention to the ways in which emotion and politics impacted upon the action learning project. Thus individual and group responses to the distribution of the unfamiliar challenge provide important space for exploring emotional and political features of practice. 


\section{The Field Experience: Navigating the unfamiliar}

The analysis further revealed that the week spent overseas working in groups to progress the agreed organisation problem, provided important opportunities to highlight emotional and political aspects of practice which for a number of reasons were heightened as groups navigated new environments. Working in a new environment could be seen to present occasion for sensemaking which accordingly was imbued with emotion (Weick, 1995). In dealing with emotion stimulated by the unfamiliar, Weick (1995) highlights that it is usual to turn to others but as the quotes below suggest, group relations in this setting were seen to complicate rather than support since others were also little known:

'Just being away for a week with people that you don't know that well, you know you have seen them every few weeks but you haven't spent a whole week with them' [Logistics Leader]

'Being away with people you know that you get on with but being in a different environment, a different situation, a pressurised situation, they [other group members] are away from home, I am away from home and there were tensions' [Deputy Chief Executive]

The quotes highlight the fragility of group relations in the unfamiliar environment which raised issues which would usually be unquestioned. For example, groups were cautious in assigning a leadership role since this was seen to further jeopardise group relations: 
'We shied away from appointing a project manager, I think to do with status, we didn't really have any clarity of leadership' [Operations Centre Manager]

'I think with hindsight I can see that we were all equals in the group, there was no clear leader, we didn't have a project manager as such focusing on the delivery of the project [Logistics Support Manager]

These quotes suggest that group working in an unfamiliar environment can heighten emotional fears of 'taking the lead' and political fears since 'taking the lead always has an impact on the social system' (Vince, 1996: 122) as well as providing opportunity to consider what a leader should or should not be. It is therefore suggested that the international dimension of action learning here which placed managers in an unfamiliar and pressurised environment provided peculiar opportunities for educators to raise awareness of taken for granted aspects of practice.

The analysis further revealed that both positive and negative consequences followed from the delicate group relations. For example, one individual commented that

'We were all different, we all looked at the project in different ways and took different spins on it and you think that is interesting, I hadn't thought about it like that, so you become more of a team member, rather than thinking my way is best' [Manufacturing Manager]. 
This suggests the positive benefits of 'comrades in adversity' working together (Revans, 1982). However, differences were sometimes problematic with the pressures of the international assignment weighing heavy:

'Things got a bit fractious; we were managing the pressure of time and the social element [Logistics Manager]

'There were a few tears and tantrums that week, only one set from me but that was because I had been up all night working on this bloody thing.' [Chief Executive]

and sometimes resulted in grave problems

'When we got there, this one person took over completely and I didn't know how to deal with that. I found that very difficult to cope with. This particular person couldn't see where we were coming from, we couldn't see where she was coming from, well I think we could actually, that was the problem. We could see where she was coming from [promoting her career] but we didn't like it and we just hit a brick wall....We had all done Belbin and Goldie profiles before we went and thought we could work together and then when we got there we couldn't... And I think the net result was that we put a bloody awful project together which failed'. [Business Development Manager] 
These examples demonstrate the ways in which the group working requirement of action learning presented further challenges in negotiating the unfamiliar and are more illustrative of 'adversaries with commonality' (Vince, 2004) highlighting an awareness of negative emotions which are also mobilised when groups work together. The latter example in particular draws attention to the ways in which such emotion interacts with the politics of the group highlighting how the different agendas of group members revealed themselves in action and proved difficult to cope with, especially since group inventories had proposed the compatibility of the group and which the group had placed great faith in. Taken together, the examples illustrate that making sense of the new environment provided special opportunities to recognise the interaction of emotions and politics. The usual emotional response to the unfamiliar is heightened by and informs fragile group relations. The unusually precarious state of group dynamics seemingly permits acknowledgement of aspects of practice otherwise taken for granted.

Further, the international setting of action learning also provided unique opportunities for ordinarily unseen broader political concerns to show themselves. The accounts suggested an increased awareness of what Vince (2004) has referred to as 'social politics'. Descriptions of the projects suggested that the new environment provided an experience of 'otherness' (Chia, 2010) which was significant in exaggerating societal differences. In turn such exaggeration helped to raise awareness of the ways in which such factors inevitably shape practice. For example, the illustrations below describe 
how action learning in international contexts drew attention to differences in societal contexts:

'I will never forget the project we did in South Africa because they had just come out of apartheid and you could see so many things that you had studied in previous years, you talk about political context....that was absolutely fascinating to see". [Training Services Manager]

'I was able to see how they (Malaysians) trade quite differently to us. They put an awful lot of emphasis on trust and honourablness whereas we tend to be quite cash focused'. [Contracts Manager]

Both accounts show an attention to broader organisational contexts which implicate on 'how we do things here' (Vince, 2004) and the values which inform management practice (Grey, 2004). The accounts highlight a sense of some increased awareness of the ways in which wider social politics informed practice in the host organisations. Importantly, this, as we shall see later, also provided implications for managers' everyday practice.

\section{Project Assessment: Assessing the unfamiliar}

The final stages of the project involved the production of the written report to offer recommendations for organisational action. However, it also presented additional possibilities for developing understandings of the emotions and politics of practice as students sought to make sense of assessment requirements. Notably, students highlighted the unfamiliar challenge of meeting both the needs of the host organisation and the university '/ wanted to make sure that we did a good project but within that there was a difference 
between what the university wanted and what the business wanted, and there was definitely a balancing act there to try and please both' [Operations Centre Manager]. This unusual challenge raised both emotional and political issues. Firstly, students were concerned to deliver to the organisation given the extended hospitality and the close relationships formed during the overseas visit 'We were really lucky because the country representative of [host organisation], who I organised it with, actually said well you can come and stay at our house. And he opened up his house to us' [Communications Manager], thus demonstrating the ways in which emotional closeness informs practice. Secondly, the students were simultaneously aware of the need to fulfil assessment requirements which surfaces issues of power and authority since the demands of assessment highlight the political dimensions of management education itself and the authority of the educator (Elliott, 2005). The challenges of meeting the needs of the client and the needs of assessment have been previously noted (Lammond, 1995) but have been under explored as an opportunity to raise awareness of emotional and political aspects of practice.

Students' accounts also highlighted the significance of broader social politics in producing the final report. In making recommendations, consideration of the societal context was evoked, and in particular an awareness of the power relations between the host organisation and the MBA students.

'You also have the culture and the fact that these people were so passionate about their business, you have got to be really careful not to patronise them or not to put forward suggestions that were out of their 
reach. We were visiting schools that were so poor and the last thing they want is some MBA students coming in telling them what to do'. [Product Manager]

This kind of increased sensitivity to broader social relations often remains unacknowledged in everyday management practice. The potential of action learning in international contexts for developing organising insight is again illustrated since the differing cultural values of the international setting permit a sharpened focus on social politics which surround practice. Once more, this demonstrates the value of 'otherness' in deepening understandings of practice (Chia, 2010).

Insert Table 1 around here

\section{Project Outcomes: Returning to the familiar}

Having highlighted how the various stages of the international action learning projects presented rich opportunities to raise awareness of emotional and political features of practice, it is now important to consider the outcomes for managers' everyday practice. Importantly, the international projects which raised awareness of emotions and politics which surround learning and organising allowed managers to see such dynamics in their own settings which previously had been unseen. Moreover, and in line with critical management hopes, this in turn stimulated a questioning of known ways of making sense of the world (Cunliffe, 2002), which provides some hope for transformation of accepted practice. The outcomes of action learning here 
thus progress beyond the more instrumental questioning characteristic of Revans's original ideas.

The examples below illustrate how an awareness of emotion and politics in the unfamiliar setting of the action learning projects, facilitated an understanding of such dynamics in everyday settings:

'In terms of the mindset in terms of how I approach things, it is difficult to quantify that, I think it maybe to do with confidence. I probably approach things differently as I look toward the group dynamics more than I did' [Logistics Manager]

'There are cultural differences, you see they exist within organisations but are often subtle, so you don't see them. Being put in the extremes of cultural differences, you can't help but notice cultural differences and so then this increases your awareness of local ones, if you see what I mean'. [Operation Centre Manager]

These accounts demonstrate managers' increased awareness of local organisational dynamics that they took for granted but now see. Action learning in unfamiliar contexts thus provides particular hope for leveraging critical management perspectives which privilege taken for granted aspects of management practice. Indeed, illuminating the taken for granted is perhaps the central challenge for critical management educators (Samra-Fredericks, 2003).

Moreover, shedding light on aspects of practice previously unseen for some also meant a more reflexive practice as students began to "question their own 
ways of making sense of the world" (Cunliffe 2002: 4) which is also consistent with critical management perspectives which not only seek to raise awareness of the taken for granted but also to question this (Mingers, 2000).

'I think it has equipped me to be a better manager, to be able to deal with different people and different situations. It makes you sit back and think about the assumptions you might be making'. [Building Contract Manager]

'I used to judge people, well everybody does but I used to make assumptions before whereas now I stop and think about it first. I used to just assume if somebody is doing something, they are doing it for a particular reason when in fact there may be lots of other reasons why they are doing something. I think working through a translator that you start to think about how clearly you express yourself and it does make you think differently'. [Operation Centre Manager]

Both comments suggest a questioning of the assumptions they made of the behaviour of others which potentially has wide reaching implications for changing practice since organising is always complicated by our interpretations of the behaviour and motives of others (Vince, 2004). Of note, the second illustration also highlights the important contribution that language differences made to such realisations. This develops arguments made by Anderson and Thorpe (2004) who found that a heightened consciousness of language use can promote critical reflection, to suggest the importance of international language differences in stimulating such reflection. 
For some students, the questioning of practice went even further than social relations in the workplace to question issues of broader social structure:

'When I got back from Africa, the first sort of big project I had to do was to help implement a new tariff...and I am saying 'excuse me, I have just been to a country where there is no water, there is no sanitation, there is hardly any food, and you want me to help you implement a [unfair] tariff'. And I know it is the totally wrong way of looking at it, but I just could not get back into this capitalism, this commercialism'. [Communications Manager]

The example powerfully shows how exposure to 'otherness' (Chia, 2010) heightened social norms and cultural codes which distribute power and privilege. The illustration empirically demonstrates how action learning can 'open up an appreciation and sensitivity to the 'darker' aspects of organisational life' (Willmott, 1997) and thus again raises hopes of a more critical management practice. However, this is not to deny the unease that this generated for this individual which more generally provides issue for advancing critical management ideas.

\section{DISCUSSION}

Against renewed claims that action learning approaches offer potential remedy to key troubles of MBA programmes, the paper sought to provide an empirical example of action learning as used in practice on an MBA programme. This is important since ironically management educators have tended to concentrate more on the theory of action learning rather than its 
practice. The paper has demonstrated that the particular form of action learning used here was imbued with opportunities to develop 'organising insight' (Vince, 2004), that is to learn from and about the emotions and politics surrounding processes of learning and organising which ordinarily remain taken for granted. The paper thus provides empirical support for the theoretical position of Vince (2004) and importantly adds to this work by specifying conditions under which such insight can more readily develop. Specifically, it has been proposed that action learning which accentuates the unfamiliar, here the international setting, is significant in developing understandings of ordinarily taken for granted aspects of practice. More broadly, the paper offers rare empirical support for theoretical propositions which contend that action learning offers special promise for the introduction of critical management ideas (Reynolds \& Vince, 2004, Willmott, 1997).

The paper suggests that particular forms of action learning may offer unique opportunities for management educators. The paper has focused on action learning projects in unfamiliar international settings and has suggested that projects which accentuate the unfamiliar can be especially helpful in raising awareness of emotions and politics which surround learning and organising. Whilst the importance of the unfamiliar task has been previously recognised as an important element of action learning in provoking questioning insight (McGill \& Beaty, 1995), the analysis here suggests that the unfamiliar setting is particularly salient in promoting organising insight. The international location which placed the manager in an unfamiliar environment crucially provided for an unsettling experience which evoked emotion along with attention to what 
was different about the new location shedding light on differences in societal contexts and values. In addition, the manager was also working with lesser known others under pressurised conditions which amplified the challenges of working out of place since familiar social support systems were removed. The unsettling experience of action learning out of place thus provided rich opportunity for taken for granted aspects of practice to reveal themselves. Indeed, Wahlin (2006) argues that adjusting to new conditions promotes capacities that may not come more readily in more familiar settings.

Of interest, a number of scholars have written about the difficulties faced by international students who travel to study on UK MBA programmes (Griffiths et al., 2005; Currie, 2007; Simpson et al., 2010). Griffiths et al. (2005) for example liken the experience to 'culture shock' and point to the resultant frustrations, anxieties and confusion. Nevertheless, such studies recognise the potential for profound learning from such unsettling experiences. In the example here, we see home students experiencing a similar 'shock' albeit of a milder kind which likewise presents opportunities for significant learning. Indeed, it is telling that even after some time since the completion of the action learning projects recounted here, the value of the learning has faded little.

Moreover, the unsettling experience of the action learning projects here can be seen to be particularly significant for leveraging critical management ideas. Plausibly, there is a need to disrupt managers accepted ways of knowing and being in order for taken for granted aspects of practice such as emotion and 
politics, to be seen and in turn questioned. Action learning projects which accentuate the unfamiliar can provide management educators with possibilities for unsettling practice and promoting more critical understandings of practice.

Arguably, encounters with the unfamiliar are more readily available in management education contexts since managers are removed from their day to day work settings. It is suggested that we need to embrace this opportunity rather than deny it in seeking to help managers better understand their practice. Indeed, discussions which explore the role of the business school, suggest that it is wise to preserve what might be unique in management education (O'Toole, 2009). Others also warn educators about unquestioningly adopting approaches deemed useful and relevant by business (Knights, 2008; Learmouth \& Lockett, 2010). In relation to the specific use of action learning in management education, caution might be applied to claims that action learning should work exclusively with managers' everyday work (Gosling \& Mintzberg, 2006). Whilst it is not disputed that there is obvious value in helping managers to explore their everyday practice, working with managers' everyday practice exclusively in an attempt to get closer to practice, may restrict understanding since such closeness often blinds us to salient aspects of practice. Indeed, Chia (2010) contends that experience of otherness is crucial to learning since insight is gained through contemplating difference, yet in management education this is not sufficiently encouraged. As we have seen here, the removal of the manager from everyday settings provided opportunities for taken for granted aspects of managerial work to reveal 
themselves which in turn allowed them to see their own practice differently as we see in the following comment:

'If you can only ever see the way that you own organisation works you have no experience beyond that you are not going to be able to make any meaningful changes because all you are going to be able to do is use or do what you have always done. So by seeing the way that others do things it can spark ideas as to how you are going to do things differently'. [Training Services Manager]

Therefore working with the unfamiliar in action learning can plausibly develop managers' capacities to reflect on action already taken which Mintzberg (2004) suggests should be a fundamental aim of management education. In particular, it is suggested that reflecting on taken for granted aspects of practice such as emotion and politics may be difficult to achieve working solely with managers' familiar experiences.

\section{RECOMMENDATIONS}

The paper offers recommendations for enhancing the use of action learning in management education in its attempts to speak more closely to management practice. Importantly, much might be achieved in the reframing of the way educators think about action learning. It is suggested that it is helpful to think about action learning as process of organising as well as a process of learning (Vince, 2004). This means that in addition to an involvement in a 
problem solving task, action learning might be seen to involve engagement with emotional and political dynamics and as such presents educators with opportunities to raise awareness of these dynamics. This recognises that learning processes mirror organising processes which provide exceptional opportunities for learning about practice. However, Armstrong and Fukami (2009) argue that such opportunities are typically neglected.

If action learning is to be reframed in this way, conceivably assessment might well require change too. Assessment is especially important since it has a powerful impact on the ways in which students perceive what is important in the learning situation. In addition to assessment requirements which demand recommendations for action and a well executed problem solving task, there might be an explicit requirement for students to also focus attention on the process of organising involved in action learning projects with a particular emphasis upon emotional and political aspects of learning and organising. As Vince (2010) argues educators rarely encourage reflection on the emotions and politics generated in management education and the paper here suggests that this ignores significant learning opportunities. As we have seen here, there was evidence of students' reflecting on emotional and political aspects of learning, however this was not an explicit requirement of the programme and much more could be made of this informal learning outcome. For example, follow up assessments which encourage consideration of implications for local practice can strengthen learning from the unfamiliar setting. Moreover, such consideration can provide opportunity for the 
introduction and potentially increased receptivity to critical management theory, and possibilities for promoting reflexive practice.

Further, the paper offers specific recommendations for the use of action learning projects in international settings. Educators might seek to shape such projects to leverage the benefits of 'unsettling' experiences which have been demonstrated to be crucial in unlocking taken for granted aspects of practice. Firstly, it is important to offer students' autonomy in project set up as this mobilizes anxiety associated with learner responsibility (Vince, 1996) as well as allowing political concerns to show themselves as individuals work together to define their problem. Secondly, whilst respecting the autonomy of the students to shape their projects, faculty may wish to manipulate the make up of the groups to ensure where possible those from different occupational areas work together. This is important as diversity in group membership draws particular attention to group politics. Thirdly, if possible students should be encouraged to work with individuals that they have not previously worked with since working with lesser known others heightens emotion. Fourthly, it is recommended that students are encouraged to visit locations that have not previously been visited. This is important as the student is forced beyond their 'comfort zone' which allows opportunities to explore the ways in which emotion informs learning as well as highlighting broader politics.

Finally, the paper also suggests that there is a need for further research which explores the use of different forms of action learning as used in management education to increase understandings of how different forms may provide 
particular advantages in developing understandings of management practice. In addition, research which adopts a longitudinal design and monitors the progression of action learners over time can provide more detailed understandings. Generally, there is value in research which furthers understanding of how teaching approaches are actually experienced by students in attempts to better link teaching approaches to practice (Currie \& Tempest, 2008). As we have seen here, much might be said for developing and leveraging understandings of informal learning.

\section{CONCLUSION}

Action learning approaches are seen to offer promise to troubled MBA programmes in providing increased attention to practice. Some have interpreted this to mean that there is a need for MBA programmes to privilege action learning approaches which involve managers learning from their everyday practice (Gosling \& Mintzberg, 2006). However, the paper has argued that educators should recognise the plurality of forms action learning can take rather than assuming that there is one best approach to the use of action learning in management education contexts. It is suggested that different forms of action learning may provide different opportunities for management educators. It is therefore important to understand how different forms of action learning are applied in practice in management education contexts. 
The paper has provided an empirical consideration of an application of action learning in management education: an international consultancy project. The benefits of action learning in international settings have not previously been documented, and the paper has demonstrated that action learning in international settings which removes the manager from everyday practice provides unusual opportunities for developing 'organising insight' (Vince, 2004), that is raising awareness of emotions and politics which surround learning and organising which ordinarily remain unseen. Crucially, it has been argued that the unfamiliar international setting provides for an unsettling experience which is especially significant in illuminating these taken for granted aspects of management practice. More broadly, forms of action learning which work with the unfamiliar thus offer particular promise for critical management educators who are challenged to elucidate taken for granted aspects of management practice. To get closer to critical understandings of management practice perversely it might firstly be necessary to move away from everyday practice. 


\section{REFERENCES}

Anderson, L., \& Thorpe, R. (2004). New perspectives on action learning: developing criticality, Journal of European Industrial Training, 28 (8/9), 657668

doi: $10.1108 / 03090590410566570$

Antonacopoulou, E., \& Gabriel, Y. (2001). Emotion, learning and organisational change. Towards an integration of psychoanalytic and other perspectives. Journal of Organisational Change Management, 14 (5), 435451.

doi:10.1108/EUM0000000005874

Armstrong, S. J., \& Fukami, C.V. (2009). Past, present and future perspective of management learning, education and development. In S.J. Armstrong \& C.V. Fukami (Eds.), The SAGE Handbook of Management Learning, Education and Development (pp.1-22). London: Sage.

Bailey, J., \& Ford, C. (1996). Management as science versus management as practice in postgraduate business education, Business Strategy Review, 7 (4), 7-12.

doi:10.1111/j.1467-8616.1996.tb00136.x

Bennis, W., \& O'Toole, J. (2005). How business schools lost their way, Harvard Business Review, 83 (5), 96-104. 
Chia, R. (2010). Shifting paradigms through "letting go": On allowing oneself to become a management educator scholar. In C. Wankel and R. Defillipi, (Eds.), Being and Becoming a Management Education Scholar (pp.11-41). Charlotte, NC: Information Age Publishing.

Cunliffe, A. L. (2002). Reflexive Dialogical Practice in Management Learning, Management Learning, 33 (1), 35-61.

doi:10.1177/1350507602331002

Currie, G, (2007). Beyond our imagination: the voice of international students on the MBA, Management Learning, 38 (5), 539-56.

doi:10.1177/1350507607083206PMid:15929407

Currie, G., \& Tempest, S. (2008). Moving towards reflexive use of teaching cases within the MBA. International Journal of Management Education, 7 (1), $41-50$.

doi:10.3794/ijme. 71.205

DeFillippi, R.J. (2001). Introduction: Project-based learning, reflective practices and learning outcomes. Management Learning, 32 (1), 5-10. doi:10.1177/1350507601321001

Dehler, G. (2006).Using action research to connect to learning: a course project for working management students, Journal of Management Education, 
30 (5), 636-669.

\section{doi:10.1177/1052562905277302}

Elliott, C. (2005). Experiential management education and the emotional politics of learning. How might this inform critically reflexive pedagogies? 4th International Critical Management Studies Conference, Cambridge, UK, $4^{\text {th }}-6^{\text {th }}$ July.

Fineman, S. (1996). Emotion and organizing. In S. Clegg, C. Hardy and W. Nord (Eds.), Handbook of Organization Studies (pp.543-64). London: Sage.

Gentle, P. (2010). The influence on action learning set of affective and organisational cultural factors, Action Learning: Research and Practice, 7 (1), 17-28.

$\underline{\text { doi: } 10.1080 / 14767330903576820}$

Gosling, J., \& Mintzberg, H. (2006). 'Management Education as if both matter', Management Learning, 37 (4), 419-428.

doi:10.1177/1350507606070214

Grey, C., Knights, D., \& Willmott, H. (1996). Is a critical pedagogy of management possible? In R. French and C. Grey (Eds.) Rethinking Management Education (pp.94-110). London: Sage. 
Grey, C. (2004). Reinventing Business Schools: The Contribution of Critical Management Education, Academy of Management Learning and Education, 3 (2): 178-186.

Griffiths, D.S., Winstanley, D., \& Gabriel, Y. (2005). Learning shock. The trauma of return to formal learning, Management Learning, 36 (3), 275-297. doi: $10.1177 / 1350507605055347$

Harris, P. (2006). Questioning in Action Learning: Rhetoric or Reality, International Journal of Management Education, 5 (2), 15-20. doi:10.3794/ijme.52.108

Hay, A., \& Hodgkinson, M. (2006). Exploring MBA Career Success. Career Development International, 11 (2), 108-124.

Hay. A., \& Hodgkinson, M. (2008). More success than meets the eye: a challenge to critiques of the MBA. Possibilities for Critical Management Education? Management Learning, 39 (1), 21-40

Inglis, S. (1994). Making the Most of Action Learning. Brookfield,VT: Gower.

Johnson, C., \& Spicer, D. (2006). A case study of action learning in an MBA program. Education and Training, 48 (1), 39-54.

doi: $10.1108 / 00400910610645725$ 
Knights, D. (2008). Myopic Rhetorics: Reflecting epistemologically and ethically on the demand for relevance in organizational and management research, Academy of Management Learning and Education, 7 (4), 537-552.

Lammond, D.A. (1995).Using consulting projects in management education. The Joys and Jitters of serving two masters, Journal of Management Development, 14 (8), 60-72.

\section{doi: $10.1108 / 02621719510097433$}

Learmouth, M., \& Lockett, A. (2010). The uselessness of useful education and the usefulness of useless education, Academy of Management Meeting, Montreal, Canada, $6^{\text {th }}-10^{\text {th }}$ August.

Leavitt, H.J. (1989).'Educating our MBAs: On Teaching What We Haven't Taught', California Management Review, 31: 38-50.

Marquardt, M.J. (1999). Action learning in action: transforming problems and people for world class organisational learning. Palo Alto, CA: Davies Black Publishing.

Marquardt, M.J., \& Waddill, D. (2004). The power of action learning: a conceptual analysis of how five schools of adult learning theories are incorporated within the practice of action learning. Action Learning: Research and Practice, 1 (2), 185-202.

doi:10.1080/1476733042000264146 
Marsick, V., \& O'Neil, J. (1999). The many faces of action learning.

Management Learning, 30 (2), 159-76.

doi:10.1177/1350507699302004

McGill, I., \& Beaty, L. (1995). Action Learning. Kogan Page: London.

McLaughlin, H., \& Thorpe, R. (1993). Action learning- a paradigm in emergence: the problems facing a challenge to traditional management education and development, British Journal of Management, 4, 19-27. doi:10.1111/j.1467-8551.1993.tb00158.x

Miles, M.B., \& Huberman, A.M. (1994). Qualitative Data Analysis: An Expanded Sourcebook. London: Sage.

Mingers, J. (2000). 'What is it to be Critical? Teaching a Critical Approach to Management Undergraduates', Management Learning, 31 (2): 219-237. $\underline{\text { doi: } 10.1177 / 1350507600312005}$

Mintzberg, H. (2004). Managers not MBAs. A Hard Look at the Soft Practice of Managing. Harlow: Pearson.

Navarro, P. (2008). The MBA Core Curricula of Top Ranked U.S. Business

Schools: A Study in Failure? Academy of Management Learning and Education, 7 (1), 108-123. 
O'Toole, J. (2009). The pluralistic future of management education. In S.J. Armstrong and C.V. Fukami (Eds.), The Sage Handbook of Management Learning, Education and Development (pp.547-558). London: Sage.

Pedler, M. (1991). Action Learning in Practice, 2nd edition. Brookfield, VT: Gower.

Pedler, M. (1997). Interpreting action learning. In J. Burgoyne \& M. Reynolds (Eds.), Management Learning: Integrating Perspectives in Theory and Practice (pp.248-264). London: Sage.

Pedler, M., Burgoyne, J., \& Brook, C. (2005). What has action learning learned to become? Action Learning: Research and Practice, 2 (1), 49-68.

Pfeffer, J., \& Fong, C. (2002). 'The End of Business Schools? Less Success Than Meets the Eye', Academy of Management Learning and Education, 1 (1), 78-95.

Raelin, J.A. (1994). Whither management education? Professional education, action learning and beyond. Management Learning 25 (2), 301-317. $\underline{\text { doi: } 10.1177 / 1350507694252009}$

Raelin, J. (2006). Does action learning promote collaborative leadership? Academy of Management Learning and Education, 5 (2), 152-168. 
Revans, R. (1980). Action Learning. London: Blond and Briggs.

Revans, R. (1982). The Origins and Growth of Action Learning. Bromley: Chartwell Bratt.

Revans, R. (1984). Action learning: the business of learning about business.

In D. Casey and D. Pearce (Eds.), More Than Management Development: Action Learning at GEC (pp.3-6). Aldershot: Gower.

Reynolds, M., \& Vince, R. (2004). Critical Management Education and ActionBased Learning: Synergies and Contradictions. Academy of Management Learning and Education, 3 (4), 442-456.

Rigg, C., \& Trehan, K. (2004). Reflections on working with critical action learning, Action Learning: Research and Practice, 1 (2), 149-165. doi:10.1080/1476733042000264128

Samra-Fredericks, D. (2003). A proposal for developing a critical pedagogy in management from researching organizational members' everyday practice. Management Learning, 34 (3), 291-312.

doi:10.1177/13505076030343001

Schwandt, T. A. (1994). Constructivist, interpretivist approaches to human 
inquiry. In N.K. Denzin and Y.S. Lincoln (Eds.), Handbook of Qualitative Research (pp.118-37). Thousand Oaks, CA: Sage.

Simpson, R., Sturges, J., \& Weight, P. (2010). Transient, unsettling and creative space: Experiences of liminality through the accounts of Chinese students on a UK-based MBA, Management Learning, 41 (1),53-70. $\underline{\text { doi: } 10.1177 / 1350507609350830}$

Smith, P.A.C., \& O'Neil, J. (2003). A review of action learning literature 19942000. Journal of Workplace Learning, 15 (2), 63-70.

doi:10.1108/13665620310464102

Starkey, K., Hatchuel, A., \& Tempest, S. (2004). Rethinking the business school, Journal of Management Studies, 41 (8), 1521-1531.

doi:10.1111/j.1467-6486.2004.00485.x

Strauss, A., \& Corbin, J. (1998). Basics of Qualitative Research: Grounded Theory Procedures and Techniques, 2nd Edition. London: Sage.

Vince, R., \& Martin, L. (1993). Inside action learning: the psychology and the politics of the action learning model, Management Education and Development, 24 (3), 131-152.

Vince, R. (1996). Experiential Management Education as the Practice of Change. In R. French and C. Grey (Eds.), Rethinking Management Education 
(pp.111-131). London: Sage.

Vince, R. (2004). Action learning and organisational learning: power, politics and emotion in organisations. Action Learning: Research and Practice, 1 (1), 63-78.

doi:10.1080/1476733042000187628

Vince, R. (2008). 'Learning-in-action' and 'learning inaction': advancing the theory and practice of critical action learning, Action Learning: Research and Practice, 5 (2), 93-104.

doi:10.1080/14767330802185582

Vince, R. (2010). Anxiety, politics and critical management education, British Journal of Management, 21, S26-39.

doi:10.1111/j.1467-8551.2009.00678.x

Wahlin, N. (2006). Transcultural encounters in cities: Convergence without becoming coincident, in S. Clegg and M. Kornberger (Eds.) Space, Organization and Management Theory (pp.266-86). Malmo: Liber and Copenhagen Business School Press.

Watson, T.J. (1994). Managing, crafting and researching: words, skill and imagination in shaping management research. British Journal of Management, 5, S77-S87.

doi:10.1111/j.1467-8551.1994.tb00132.x 
Watson, T. J. (2002). Organising and Managing Work. Harlow: Pearson.

Weick, K. (1995). Sensemaking in Organisations. London: Sage.

Willmott, H. (1994). Management education: Provocations to a debate, Management Learning, 25 (1), 105-36.

Wilmott, H. (1997). Critical management learning, in J. Burgoyne and m. Reynolds, (Eds.), Management Learning: Integrating Perspectives in Theory and Practice. London: Sage.

Wright, A. (2008). Finding questions through researcher sensemaking, Academy of Management Meeting, Anaheim, August $8^{\text {th }}-13^{\text {th }}$. 


\begin{tabular}{|c|c|c|}
\hline Project Stage & Features of international project & $\begin{array}{l}\text { Educator opportunities for developing organising } \\
\text { insight }\end{array}$ \\
\hline \multirow{3}{*}{$\begin{array}{l}\text { Introduction and } \\
\text { definition }\end{array}$} & Student responsibility for projects & Anxiety and fear of responsibility for significant task \\
\hline & $\begin{array}{l}\text { Student learning orientations towards } \\
\text { the project }\end{array}$ & Individual motives and desires shape project \\
\hline & $\begin{array}{l}\text { Negotiation of international project } \\
\text { location }\end{array}$ & $\begin{array}{l}\text { Individuals desires to avoid anxiety which promotes willing } \\
\text { ignorance v working with anxiety to promote new insights }\end{array}$ \\
\hline \multirow{7}{*}{$\begin{array}{l}\text { International } \\
\text { Fieldwork experience }\end{array}$} & Unfamiliar international location & Anxiety of being out of place \\
\hline & $\begin{array}{l}\text { Being out of place with lesser known } \\
\text { others }\end{array}$ & Anxiety brought about by removal of familiar social support. \\
\hline & Definition of group roles & $\begin{array}{l}\text { Emotional fears of taking the lead and political fears of } \\
\text { impact on group relationship especially power given to the } \\
\text { leader. }\end{array}$ \\
\hline & Differing occupational backgrounds & Individual agendas, beliefs and interpretations \\
\hline & Temporal intensity of project & Emotional pressure and impact upon group relationship \\
\hline & Differences in societal contexts & $\begin{array}{l}\text { Broader social politics "how we do things here" and values } \\
\text { of management practice }\end{array}$ \\
\hline & Language differences & $\begin{array}{l}\text { Translation raises awareness of assumptions of self and } \\
\text { others }\end{array}$ \\
\hline \multirow[t]{3}{*}{ Assessment } & $\begin{array}{l}\text { Expectations of host organisation and } \\
\text { university }\end{array}$ & Politics of management education and authority of educator \\
\hline & Relationship with host organisation & Emotional attachment with host influences written report \\
\hline & Differences in societal contexts & Social politics shape recommendations for action \\
\hline
\end{tabular}

Table 1: Developing Organising Insight in Action Learning in International Settings 